\title{
Sector differences in conference facility refurbishment
}

\author{
Julie Whitfield $^{1}$ and Don J. Webber ${ }^{2}$ \\ ${ }^{1}$ School of Services Management, Bournemouth University, UK \\ ${ }^{2}$ Department of Economics, Auckland University of Technology, NZ
}

\begin{abstract}
What influences the probability that a conference facility will refurbish? This is an important question as such information can inform conference organisers when selecting a venue. This paper presents an econometric analysis of the probability of conference venue refurbishment with a particular focus on the sector differences (purpose-built, educational establishments, visitor attractions and hotels) and time since previous refurbishment. We test the hypotheses that there are scale and growth effects and whether the presence of disabled facilities influences the probability that a conference venue will refurbish.
\end{abstract}

Keywords: Product development; U.K. conference sector; Refurbishments

Corresponding author: Don J. Webber, Department of Economics, Auckland University of Technology, Auckland, New Zealand. Email: Don.Webber@aut.ac.nz 


\section{Introduction}

Empirical research identifies that conference planners and delegates are increasingly demanding a high quality conference product which offers value for money. "It is important that venues upgrade and keep in tune with what the market is looking for" (Rogers cited in Chetwynd, 2001, p.41) in a bid to provide a quality conference product.

Managers of conference facilities need to be aware that the demand for their product will be influenced by the range, design and flexibility of their conference capacities, interior quality (ambience, comfort, warmth, colour, furniture, lighting, airconditioning and noise) and the provision of modern conference technology (Lawson 2000; Meetings Industry Association, 2001; Crouch and Louviere, 2004). The decision to supply and improve the quality of supply of these facilities will be dependent on a range of factors including costs which will be affected in turn by the provision of disabled access, the size of the conference facility and whether there has been a recent growth in demand for conference facilities.

Different sectors of the conference facility market will upgrade at different rates. The probability of upgrade will be dependent on demand and supply issues highlighted above but will also depend on the rate at which improvements and innovations occur within the sector. It is therefore expected that the probability of refurbishment should vary across conference facilities. This is an important issue as such information can inform conference organisers when selecting a venue.

This paper presents an econometric analysis of the probability of conference refurbishment with a particular focus on the four venue classifications (purpose-built venues, educational establishments, visitor attractions and hotels) which together constitute the UK conference sector (Whitfield, 2005). We test whether there are scale and growth effects and whether the presence of disabled facilities influences the probability that a conference facility will refurbish.

The data analysed in this empirical research was collected during a period of transition within the UK. After 18 years of Conservative government, and their associated Monetarist policies, the Labour Party gained power in 1997. It set about implementing post-Thatcherism policies and by 2001, at the end of Labour's first term and the year in which our empirical data was collected, such policies had led to affirmative action placing culture at the forefront of achieving wider social inclusion, and improvements in funding (Hayes and Slater, 2002). These policy changes had a direct impact on one conference venue type utilised within this paper, that of visitor attractions, and in particular the sub-categories of museums and galleries. The implications of which are discussed in terms of possible future research.

The next section presents a review of the literature on factors that influence the probability of refurbishment with a particular focus on the differences across venue classifications and refurbishment attributes. Section 3 reviews the method, data and econometric technique. Section 4 presents and then discusses the results. Section 5 provides concluding remarks.

\section{The refurbishment of conference facilities to improve customer satisfaction}

One of the reasons why conference venues refurbish and upgrade their facilities is to achieve a high level of consumer satisfaction with the hope of repeat visitation or recommendation. The refurbishment of conference venues can be viewed as a process of rejuvenation in order to continually improve the quality of the conference 
product (Whitfield, 2005). Estimates show that the cost of poor quality to the service sector is approximately 30\% of gross sales (Tally, 1991), where quality is defined as "the consumer's overall impression of the relative inferiority/superiority of the organisation and its services" (Bitner and Hubbert, 1994, p.77). With reference to the conference sector, one aspect intrinsically linked to quality is that of customer satisfaction, with the quality of the conference product being reflected in the level of customer satisfaction (Zeithaml and Bitner, 1996; Troye et al., 1995), and customer satisfaction is achieved through the provision of a quality product (Shetty and Ross, 1985; Deming, 1986; King, 1987; Headley and Choi, 1992). Conference facilities across the four UK venue classifications - purpose-built venues, hotels, educational establishments and visitor attractions - have undertaken refurbishment activities in order to rejuvenate their product, as outlined below.

\section{Purpose Built venues}

Purpose-built venues were the pioneering conference venue classification within the UK conference sector and with many of these venues now approximately 30 years old (Whitfield, 2005) modernisation is necessary to remain competitive in today's market (Chetwynd, 2001). Many purpose-built venues have undertaken some form of refurbishment and/or construction programme to improve their existing conference products (Whitfield, 2007). Empirical evidence is available on refurbishment and the relative importance of flexible room designs that permit smaller breakout sessions along with the provision of modern, appropriate technology with a good standard of décor and the ability to accommodate delegates (Meetings Industry Association, 2000; Robinson and Callan, 2003; Crouch and Louviere, 2004).

Examples of refurbishment can be seen within purpose built centres. In 2003, the Bournemouth International Conference Bureau (BICB) was established (Daily Echo, 2003) and described as "the towns official one-stop shop offering a full and impartial service to conference, meeting and event planners” (Bournemouth International Conference Bureau, 2007, online). BICB's aim is to attract conferences, meetings and events to Bournemouth through the provision of services including finding a venue and overnight accommodation for delegates (ibid). However, in the knowledge that "Bournemouth has been losing valuable conference trade because the Bournemouth International Centres' facilities were not up to scratch" (Bournemouth Borough Council, 2006a) a £22m refurbishment programme was initiated. In October 2005, the Bournemouth International Centre (BIC) reopened after the completion of this refurbishment programme. This programme included the complete refurbishment of the principal conference hall, expanding its capacity to 4,200 seated delegates in a theatre style. Additionally, a new $1,500 \mathrm{~m}^{2}$ conference hall has been created with a capacity of 1,600 seated in a theatre style. The foyers, front of house, catering and car parking facilities have also been improved (ConferenceVenues.com, 2008). Overall, the flexibility introduced through the refurbishment programme now permits events to occur simultaneously.

The net effect of providing refurbished facilities alongside promotional activities has resulted in bookings being place up to 2014 (Bournemouth Borough Council, 2006a; 2006b), turnover has increased by 50\% in the first full year of operation since refurbishment, with turnover being better than the predicted value for 5yrs on (Joint Consultative Committee, 2007). In July 2008, the International Association of Congress Centres (IAPC) voted the BIC as one of its finalists in the 
2008 AIPC Apex Award for the World's Best Convention Centre (International Association of Congress Centres, 2008).

Hotels

Hotels have restructured towards the provision of conference facilities, enabling under-utilised resources and infrastructure to be put to profitable use whilst increasing occupancy rates (Shallcross, 1998; British Association of Conference Destinations, 2002).

Hotels attract corporate conferences, meetings and events. The corporate conference sector contains a number of unique characteristics. They tend to have a small number of delegates, generally less than 100 , with the majority being attended by between 26 and 50 delegates (Robinson and Callan, 2001), and are often short in duration (Lawson, 2000). Research from within the UK identifies that $50 \%$ of corporate conferences were attended by 100 delegates or less and that $40 \%$ lasted for one day only. In light of these facts, the majority of corporate meetings have short lead times and are held within hotel facilities as part of an incentive package to their delegates (British Tourist Authority, 1998). As a result, in 2006, hotels hosted 61\% of all conferences held in the UK (British Association of Conference Destinations, 2008) and are invariably the main beneficiaries of conference business, with delegates spending more than leisure tourists. Hoteliers have increasingly accepted that conferences represent a lucrative all year round market, with delegates spending on average $£ 99$ per night compared to $£ 56$ spent by leisure tourists (Baker, 2008). In most destinations, some $60 \%$ to $65 \%$ of total delegate expenditure is on accommodation and meals in hotels even where the main venue for conferences is elsewhere (Davidson and Cope, 2003). Hotels have recognised the monetary value and related benefits and regard it as a high yield and lucrative area that provides a positive revenue stream and a means to contribute to a profit (McCabe, 2002).

Although hotel refurbishment is not a new phenomenon, hotel conference venues have also rejuvenated specifically to attract both new and repeat visitation (Richards and Richards, 1994; Whitfield, 2010). Large scale refurbishment programmes started in the 1970s and government assistance to the UK hotel industry came in the form of the Development of the Tourism Act (1969). Part I of this Act established the tourist authorities and the tourist boards for the UK, and part II provided financial assistance for hotel development in the form of the Hotel Development Incentives Scheme. Grants of up to $£ 1000$ per bedroom were provided for renovations to their existing facilities, extensions or alterations to existing hotels and for the provision of certain fixed equipment that commenced before April 1971, and had been completed by April 1973 (Borer, 1972; Taylor and Bush, 1974).

Refurbishment within hotel conference venues can also be identified. The Macdonald New Blossoms Hotel in Chester underwent a £3m refurbishment programme in the first quarter of 2007. Refurbishments of both the guest rooms, including restoration of the lead windows and provision of LCD televisions, complimented the technical upgrade of conference facilities (Macdonald, 2007) and revitalised the hotel (Johnson, 2007).

\section{Educational establishments}

In the UK since the year 2000, more than $£ 200 \mathrm{~m}$ has been invested in new facilities and the rejuvenation of older facilities by British Universities Accommodation 
Consortium (BUAC) to upgrade lecture rooms, banqueting facilities and substantial investment in the standard of student accommodation. Feedback from delegates using educational conference facilities shows that they get a more dedicated service in educational establishments than from some 4 star or 5 star hotels, as they provide a more customer-centric approach (Pemble, 2002). Educational establishments are now characterised by practical conference rooms providing good quality audio-visual equipment (Doyle, 2001) that are marketed specifically as conference venues.

In order to address the conflict between the availability of resources and aligning with the conference season, many educational establishments have in recent years constructed purpose-built conference facilities, which are available throughout the year (Rogers, 1998). For example; the University of Sheffield has undertaken a $£ 160 \mathrm{~m}$ redevelopment of its conference facilities and accommodation, creating two new villages equipped with over 4,000 en-suite bedrooms, flexible meeting space, café, bar and dining facilities. This redevelopment was completed in 2007, and the first phase of the development, The Endcliffe Village, has 3,000 newly built en-suite bedrooms and two conference venues (Peak District, 2009). A second example can be seen at Pembroke College, Oxford, which was built in 1699. It undertook a refurbishment programme in 2005 which focused on the provision of en-suite bedrooms, a fully-equipped kitchen and conference room equipped with integrated digital projector, stereo sound system, disabled access and induction hearing loop (Conference Oxford, 2005). A further example can be seen at the John McIntyre conference centre which is located at the University of Edinburgh with a new extension that opened in November 2009. The building has been fully refurbished and extended to create a flexible high-capacity conference venue. The extension adds a $378 \mathrm{~m}^{2}$ room and two executive boardrooms to compliment four existing rooms (EdinburghFirst, 2009; University of Edinburgh, 2009). The research by Doyle (2001) and Rogers (1998) has shown that through refurbishment and investment, educational establishments have increased their service quality though the provision of a high quality conference products and accommodation.

\section{Visitor Attractions}

Visitor attractions with conference facilities range from castles, country houses and historic buildings with or without accommodation, museums, galleries, fun parks, boat, trains, sport and leisure centres and theatres. Examples are seen in Madame Tussaud's in London, Haynes Motor Museum in Yeovil, Legoland in Ascot, the Eden Project in Cornwall, the Globe Theatre in London, and Alton Towers in Staffordshire (Gosling, 2002; Pemble, 2000; Nicholson, 2000; Saunders, 2001; Wills, 2002). Indeed, Alton Towers achieved the Gold Award for 'Best Unusual Venue' for the second year running, at the Meetings and Incentive Travel Awards 2008 (Alton Towers, 2008).

Initially such venues converted space or utilised unused rooms to provide conference and meeting rooms (Leask and Hood, 2000). In recent years, there has been a change in the type and style of facilities offered by these venues (Leask and Digance, 2001). A greater sophistication can be seen in many of the new facilities offered; in particular purpose-built conference facilities are being added to the visitor attraction to capture conference business (Swarbrooke, 1996).

Many visitor attractions enter the conference market based on perceived demand, rather than evidence of real demand (Leask and Hood, 2000), suggesting little research is carried out before the visitor attraction diversifies its product to 
supply such facilities. Visitor attractions enter the conference market with the aim of increasing the number of revenue sources and to use their facilities to their maximum capacity (Whitfield, 2009). Changing funding systems through the 1990s and increased competition for leisure spent within the UK has resulted in many properties having to generate additional revenue or look to alternative business mixes (Leask and Hood, 2000). However, there have been positive changes to funding streams for visitor attractions, and museums and galleries in particular; some were instigated after our data collection phase and this may have implications for future research.

\section{Changes to visitor attractions (museum and gallery) funding}

Post election victory in 1979, the Conservative government focused on implementing Monetarist policy. With it, came a commitment both ideologically and politically to introduce financial pressure in order to increase the public sector's accountability and the emergence of a commercial ethic described as 'self-help' (McPherson, 2006). By the late 1980s this resulted in concerns being expressed regarding museums:

"In pushing museums towards a self-help policy they are being asked, in effect, to raise funds in the corporate sector, charge admission, derive profits from their shops, and so on, in order to fund the depreciation on their increasingly expensive capital assets. The collections are inalienable, held in public trust for today and tomorrow. So they have no cash value. Money cannot and should not be borrowed against them" (Cossons, 1989, p. 193).

However, with financial cuts taking place in real terms throughout the 1990s, this was exactly what was demanded of public museums (Fopp, 1997; Baxter 2004). In particular museums and galleries have been negatively affected by this reduction in central and local government funding (Leask et al., 2000) as they were seen as providing an educational experience for the public, relying on grants provided by the local authority or government, or from entrance fee revenue (Leask and Spiller, 2002).

The change in political ideology that occurred with the election of the Labour Party in 1997, and with it the use of culture as a tool to arrest social problems, is well documented (Babbidge, 2000; Morris; 2005; McPherson, 2006; Bowden, 2009). ${ }^{1}$ In July 1998, a year after taking office, the Labour Party issued a document entitled 'A New Cultural Framework’ (Department for Culture, Media and Sport (DCMS), 1998). This document set out five pledges in relation to museums and galleries. The third pledge, and the one relevant to this research, was free admission for all to national museums and galleries. By April 2000 free access for all was a reality (Bowden, 2009). In 1998 funding of $£ 280 \mathrm{~m}$ over three years was announced for the DCMS in support of free access (Anon, 1998). In a little under two years, the primary income source for museums and galleries had been abolished, and in its place a yearly grant irrespective of visitor numbers was implemented. Figures show that in 2008-09 almost 9 million extra visits to former charging museums took place (DCMS, n.d).

In 2001 a further study, entitled the Renaissance of the Regions, brought about a programme to modernize and improve museums and galleries. Based on this programme, in 2004 a further $£ 15 m$ per annum was secured for the 2007/8 financial

It is not the authors' intention to provide a further in-depth analysis of the political, economic and socio-cultural history of the Labour Party's term in office, but rather to précis the pertinent temporal events in the context of this paper. 
year, above and beyond the additional £30m secured from 2005/6 (Morris, 2005). In October 2007, it was announced that investments in Renaissance of the Regions programme would rise from $£ 45 \mathrm{~m}$ in $2007 / 8$ to $£ 48.7 \mathrm{~m}$ in $2010 / 11$. Government investment in museums and galleries between 2002 and 2010/11 was predicted to reach almost £300m (Purnell, 2007).

Alongside this government funding came Heritage Lottery Funding (HLF). A non-departmental public body accountable to Parliament via the DCMS. It was established under the Conservative government in 1994, at the commencement of the UK National Lottery (Heritage Lottery Fund, 2009). Prior to its commencement museums and galleries found obtaining funding difficult, remembering that the 1990s were a period of real term cuts in museum and gallery funding (Baxter, 2004). Prior to the National Lottery, British museums were described as "tatty and tired" in comparison to other European countries and North America (Selwood and Davies, 2005).

The HLF offer two generic funding programmes: "Your Heritage" for projects from $£ 5000$ to $£ 50,000$, and "Heritage Grants", for projects of over $£ 50,000$. There are a number of targeted funding programmes, and a recent relevant initiative entitled "Collecting Cultures" which funded the strategic acquisitions for museum and galleries (Clark and Maeer, 2008). The HLF distributes approximately £180m per annum to heritage projects across the UK. Projects involving museums, parks and historic places to archaeology, natural environment and cultural traditions, in particular between 1994 and 2006, it granted over $£ 1.2 b n$ to over 2,000 museum and gallery projects including: $£ 141 \mathrm{~m}$ for acquisitions, £860m for refurbishments and construction, $£ 227 \mathrm{~m}$ on collections management, exhibitions, education and outreach (Stancliffe, n.d; Heritage Lottery Fund, 2009).

HLF funding to existing museums and galleries within the UK has been an enabler. Capital developments including building renovation, installations of displays and extensive refurbishments at both the national and local levels, rather than the creation of new facilities have al occurred (Heritage Lottery Fund, 2002; Morris, 2005; Selwood and Davies, 2005). Grants were not permitted to act as a means to recoup lost revenue. As such there was a desire by museums to source alternative revenue streams to match additional or new financial commitments, which had resulted from HLF-funded capital developments (Rottenberg, 2002; Selwood and Davies, 2005; McPherson, 2006).

This desire to diversify revenue sources mirrored further tenets in the Labour Party's post-Thatcherism social policy. The concepts of best value, performance management and commercialisation all focused museums and galleries towards the commodification of cultural assets. Elwood and Davies (2005) examined this commodification of cultural assets within London museums between 1999 and 2003. Those venues that had improved their visitor offering (1) adopted free entry over paid admission, or (2) had received HLF investment, or (3) had introduced improved exhibitions / public programmes received significantly improved visitors numbers. Whereas those venues that had not undertaken (1), (2) or (3) above experienced a decline in visitor numbers.

\section{Refurbishment attributes}

In addition to this desire to increase revenue sources is the fact that there are few barriers to entry to the conference market. Venues with the necessary facilities (room, table, chairs and basic equipment) can supply an area for such activity and thus enter 
the conference market (Leask and Hood, 2000). To those outside the sector, offering conference facilities is considered very attractive as it is viewed as simply using otherwise empty space (Davidson and Cope, 2003).

An example of this can be seen at Twickenham Stadium. The stadium's South Stand is being developed to provide both onsite accommodation and an additional $5,000 \mathrm{~m}^{2}$ of conference and exhibition space. This will include a purpose-built conference auditorium and a 4 star hotel with 156 bedrooms, with six of these being VIP suites overlooking the pitch. The redevelopment was completed in September 2008. Accompanying the new conference facilities is the 'Twickenham Experience', whereby conference delegates can undertake a tour of the stadium, the players' tunnel and museum (Twickenham Experience, 2008).

Many venues that enter the conference market purely to broaden their revenue mix, would start by offering the most basic conferencing facilities. Additionally, they are able to assess the market before investing heavily. There are many refurbishment activities that the UK conference sector can undertake. Stipanuk and Roffmann (1996, adapted by Hassanien and Losekoot, 2002, p. 233) identified three broad categories of hotel refurbishments. However, these refurbishment categories can be applied to all venue classifications that constitute the UK conference sector. The three refurbishment classifications are:

1. Minor renovation. The replacement or renewal of some non-durable furnishings (e.g. carpeting) and finishes, without changing the use or physical layout, whilst maintaining the venues image.

2. Major renovation. The replacement or renewal of all furnishings, equipment and finishes, to partially improve the venues image. This may include extensive modifications to the physical space and/or upgrading the former mechanical and/or electrical systems.

3. Master renovation. Has a greater extent than major renovation, involving the entire property changing partially or totally the image of the venue (i.e. a new structural extension).

Refurbishments not only occur with regards to the physical structure of the conference venue, as well as the furnishings and decor, but also to the conference related technical services. Rogers (1998) suggests that conference organisers are looking for venues which contain technological facilities such as a video-conferencing and satellite facilities in the building, as well as facilities for different catering needs, a registration area and crèche facilities. If conference venues desire to stay competitive within the market place, venues must continually update their conference facilities and technology. Although Robinson and Callan (2003) identified that the subset 'meeting room tangibles', including audio-visual equipment and state of the art communications, was only the sixth most likely to be refurbished, many venues have indeed refurbished their technical facilities. It should be noted however, that many venues may outsource the provision of technical equipment when needed, rather than purchase the equipment, due to the initial cost of conference technology (Chetwynd, 2001).

Legislation that has had a significant impact on the UK conference sector is that of the Disability Discrimination Act (DDA) (1995 and 2005). With the introduction of the DDA disability became a considerable concern, with regards to compliance, equality and civil rights, for visitor attractions (Walters, 2009) The Act (1995), and subsequent amendments, gave disabled people the right of access to transport, 
buildings, services, work, decision-making and all the social, cultural and commercial activities of a modern and civilised society. Specific to venues, Part 3 of the DDA stated that conference venues have a duty of care; ensuring access by disabled individuals to conference facilities and/or services is as close as is reasonably possible to that offered to the general public. It should be noted that the DDA uses the term 'reasonable adjustment' to permit a range of solutions to cater for different situations. Since December 1996, when the Act came in to force, it has been prohibited to discriminate against disabled customers by refusing service, providing the service on worse terms, providing a lower standard of service and/or failure to make reasonable adjustments (British Standards Institute, 2008). Indeed, as Goodall, (2006; p58) "Society now seeks to include disabled people."

Since October 2004, where a physical feature creates unreasonable difficulty for disabled persons or prevents access to goods and/or services, reasonable steps should be undertaken to remove the feature in its entirety, make changes to the feature so that the effect is no longer present, provide a reasonable alternative means of avoiding the feature and/or providing alternative means of making the service available (British Standards Institute, ibid).

The introduction of such legislation in 1995 and 2005 has been the driver for conference venues to work alongside external organisations, such as the charity 'Tourism for All UK'. This organisation provides consultancy to venues on disabled access, such as the 'National Accessible Scheme' (NAS). NAS is a voluntary scheme to which tourism providers can subscribe, in order to accurately promote the facilities they offer to disabled or older delegates, this includes encouraging conference and meeting venues to consider a range of features which may be introduced to help disabled delegates, including the approach to the facility, ramps, steps and stairs, external stepped approach, internal stairs, doors and furniture, passageways and corridors, the conference rooms, lighting, signage, telephones, registration desk, toilets, lifts, restaurants, and staff attitudes towards disabled delegates (Ladkin and Spiller, 2000). Access should also be seen in a much wider context than simply the physical environment. Financial barriers should also be considered, such as charging additional fees for carers. Publishing conference documentation in a range of formats, large print, Braille and sign language interpretation is also essential (Walker 2009). As are attitudinal and social barriers (Shelton and Tucker, 2005)

The importance of improving the disabled facilities is apparent, first, to comply with the changes in the law and secondly, to obtain business from disabled clients. Campbell (2002, p.16) believes that many venues are in denial of the importance of investing into improving disabled facilities:

"When will venues see that meeting the needs of disabled people is not just red tape... Don't they realise the vast majority of clients will have disabled people among their delegates? Treat disabled people badly and they will take their business elsewhere or, more seriously, the venue could face a claim for damages under the Disability Discrimination Act".

Indeed, compliance with the DDA is not comprehensive, and barriers remain. These are predominantly with respect to physical constraints of historic buildings, conservation concerns, and limited funding (Goodall, 2006). 


\section{Methodology}

The literature review presented above illustrates that all types of conference venue are undertaking refurbishment activities and some of these refurbishment activities may be for specific reasons, such as the need to provide access and facilities for disabled delegates. It suggests that there may be no difference in refurbishment rates across the different types of conference venues but the identification of asymmetries in refurbishment rates across sectors is an important characteristic because would reflect differences in market characteristics or a lagging of one part of the sector behind another, while the absence of such sub-sector differences would suggest that, in this respect, all venue classification are operating with the same refurbishment perspective and that one venue classification is not significantly lagging behind others.

To identify whether there are differences in refurbishment rates across venue classifications data were sought and collected on UK conference venues refurbishment activities. The addresses of conference venues were obtained from a number of publications including The Venue: The World-wide Guide to Conference and Incentive Travel Facilities 2000/01 and The Green and Blue Book publication. Secondary sources included UK conference bureaus and local authorities, along with journals, trade magazines and British Tourism Association publications.

Four postal questionnaires were designed, one for each venue classification. The main body of surveys were allocated three months for completion, from June to August 2001 inclusive, which included reminders. A total of 438 replies were deemed valid, giving an overall response rate of $14.6 \%$. Out of a population of 300 purpose built conference venues, 53 responded, giving a response rate of $17.6 \%$. This compares to a response rate for hotels of $14.3 \%$ (286/2000), for visitor attractions of $13.6 \%$ (75/552), and educational establishments of 16.2\% (24/148).

In addition to the venue classification, four important variables are of interest here. First whether the venue had previously refurbished in the past 3 years (mean=0.583, SD=0.493). A priori expectations are that if the venue had not refurbished in the last 3 years then the quality disparity between the venue and the venue's most up-to-date competitors will be large, and this will increase the likelihood that the venue will refurbish.

Second, recognition of a change in demand, as evidenced by a change in the number of events in the last 3 years (mean=-4.923; $\mathrm{SD}=65.556$ ). A priori expectations are that if the venue had an increase in the number of events in the last 3 years then there will be an increase in the likelihood that the venue will refurbish.

Third, the larger the venue then the more expensive will be the cost of refurbishment, and this may deter refurbishment activities or stimulate smaller and more frequent refurbishment activities. A priori expectations are that the larger the floor space (mean=1575; $\mathrm{SD}=5780$ ) then the smaller the probability of refurbishment.

Fourth, the absence of disabled access (mean=0.149; SD=0.347) for a conference facility will limit the range of clientele and delegates. A priori expectations are that the absence of disabled access will increase the probability of refurbishment.

\section{Estimation technique}

Logistic regression is an econometric method for the analysis of the probability that an event will occur and is used extensively in the social sciences. The models take the following form: 
$\operatorname{logit}\left(p_{i}\right)=\ln \left(\frac{p_{i}}{1-p_{i}}\right)=\alpha+\beta_{1} x_{1 i}+\cdots+\beta_{k} x_{k i}$

where there are $n$ units with covariates $X$ and

$p_{i}=E\left(Y \mid X_{i}\right)=\operatorname{Pr}\left(Y_{i}=1\right)$

The technique examines the (logarithm of the) odds of the event occurring (where the odds is the probability of the event occurring divided by one minus that probability) and are modelled as a linear function of the explanatory variables, $X_{i}$. This can be written equivalently as:

$p_{i}=\operatorname{Pr}\left(Y_{i}=1 \mid X\right)=\frac{e^{\alpha+\beta_{1} x_{1 i}+\cdots+\beta_{k i} x_{k i}}}{1+e^{\alpha+\beta_{1} x_{1 i}+\cdots+\beta_{k} x_{k i}}}$

It is standard to estimate the parameters $\alpha, \beta_{1}, \ldots, \beta_{k}$ using maximum likelihood, and we do so by employing STATA v9 software.

\section{Results}

The results of the binary logistic regression estimations are provided in Table 1 . The dependent variable in all regressions is whether the venue is going to refurbish in the near future. This is a binary variable and has a value of 1 if the venue is going to refurbish, and a value of 0 otherwise. The values for the omnibus test of model coefficients are invariably statistically significant at the $1 \%$ level, indicating that the null hypothesis of no causal relationship between the regressors and the regressand can be rejected. The results of the Hosmer-Lemeshow tests for goodness-of-fit are statistically insignificant in all but the first regression, indicating that there is nothing to suggest that the model is inappropriate in subsequent regression estimates in all but the first set of regression results.

\section{\{Insert Table 1 about here $\}$}

We build the model gradually by first including a variable that captures whether or not the venue refurbished in the last 3 years, as presented in column 1 . This is strongly statistically significant, as it is throughout subsequent regressions, suggesting that if the venue has not recently refurbished then there is a strong likelihood that the venue wishes to refurbish in the near future. Column 2 presents an augmentation of the model presented in column 1 with the inclusion of venue category controls, where the control category is the hotel sector. These variables improve the model and the estimates now pass the Hosmer-Lemeshow test. Relative to venues in the hotel sector, and after controlling for whether the venue has refurbished in the last 3 years, it appears that educational establishments are most likely to want to refurbish in the near future, followed by visitor attractions and then purpose-built facilities.

Columns 3, 4 and 5 progressively augment the model presented in column 2 with a stepwise inclusion of variables that aim to capture the venues growth (change in the number of events in the last 3 years), size (floor space) and whether or not they have disabled access. Interestingly there appears the be no significant influences of 
venue growth, size or disabled access on the probability of refurbishment once sector and recent refurbishment controls have been taken into account.

Under the final fitted model, and as presented in column 5 , the odds of an educational establishment refurbishing are 2.177 times greater than that of a hotel facility ( $\mathrm{p}=0.086,91 \%)$. Similarly, the odds of a visitor attraction refurbishing are 1.769 times greater than a hotel $(p=0.043,95 \%)$. The odds of a purpose-built venue refurbishing are not statistically significantly different from the odds of a hotel facility.

\section{Discussion}

The results, as based upon the 2001 empirical survey and presented above, identify statistical evidence that if a conference venue had not recently refurbished, i.e. in the last 3 years, then it is 2.364 times more likely to refurbish in the near future. This provides strong empirical support for the perspective that through the implementation of refurbishment programmes venues across the UK conference sector were aiming to breathe life into outdated conference facilities and renew their lifecycle by appealing to new and repeat visitation (Richards and Richards, 1994; Whitfield, 2010).

Importantly, our results also identify clear market segmentation within conference venue refurbishment patterns in 2001, showing that it is educational establishments that are most likely to want to refurbish over subsequent years. This is a significant finding as literature published prior to the empirical study depicts educational establishments' accommodation as being 'utilitarian', of considerable age and with infrequent redecoration programmes (Paine, 1993; Seekings, 1996). Accepting their rudimentary facilities, their attractiveness to conference organisers has been their comparatively low cost and value for money (Pemble, 2002) but this 'utilitarian' viewpoint may be rapidly changing as educational establishments are upgrading their accommodation stock and conference facilities to offer a high quality conference product. Indeed, this research identifies that the probability of an educational establishment refurbishing its conference product was 2.177 times greater than that of a hotel $(\mathrm{p}=0.086,91 \%)$. Educational establishments are now characterised by practical conference rooms providing good quality audio-visual equipment (Doyle, 2001) that are marketed specifically as conference venues. As such, many educational establishments have built purpose-built venues on campus in order to offer all year around conferences (Rogers, 1998; Lawson, 2000) without being intrusive to the original educational curriculum whilst taking advantage of leisure and sports facilities. Overall, these findings demonstrate that the negativity once applied to educational establishments' conference facilities should be rejected and that such establishments are at the forefront of offering modern, upgraded facilities within the conference industry. This is a significant finding for conference organisers to consider educational establishments when choosing a conference venue, as many offer high quality, recently refurbished facilities.

The findings also depict that visitor attractions were significantly likely to want to refurbish in the years after the empirical study, and this may be a consequence of (1) the growing demand for visitor attractions with conference facilities, or (2) the increasing availability and/or value of government funding, or (3) availability / value of Heritage Lottery funding, or (4) New Labours social policy with respect to the use of culture as a tool to arrest social problems. In relation to (1) above, organisers of conferences have become increasingly competitive in choosing venues that impress delegates and look for venues that will fit the theme of their event. As such visitor 
attractions are no longer as much of an unconventional choice as they once were and indeed visitor attractions with conference facilities have a unique inspiring selling point (Bond, 2007). "They offer a more creative setting than a standard conference suite..., attractions are usually the first choice for a themed event” (Wills, 2002, p.38) and "are often more flexible than hotels in terms of access times, theming and decorating" (Saunders, 2001, p.41). There is an increased tendency to view not only the hotel conference experience, but also purpose built conference venues as homogeneous and sterile, lacking history, décor, attractiveness and the essential 'wow' factor (Whitfield, 2005; Spain 2007). Change in opinions of conference organisers who now view visitor attractions as unique inspiring conference facilities is spurring on the desire of visitor attractions upgrading their existing conference facilities to remain competitive in this growing conference sector. Factors (2), (3) and (4) also play a role in the desire to refurbish, but these causal relationships were not examined in the current research.

There appears to be no significant influences of disabled access on the probability of refurbishment once sector and recent refurbishment controls have been taken into account. The data analyzed in this research was collected in 2001 at a time when the Disability Discrimination Act (1995) was limited to ensuring venues had a duty of care to ensure access by disabled individuals to conference facilities and/or services is as close as is reasonably possible to that offered to the general public. It was not until October 2004 when physical features that prevent or create unreasonable difficulty for disabled persons to access goods and/or services that reasonable steps were legally expected to be undertaken to remove the feature in its entirety, make changes to the feature so that the effect is no longer present, provide a reasonable alternative means of avoiding the feature and/or providing alternative means of making the service available (British Standards Institute, 2008). The impact and influence of the Disability Discrimination Act (1995) may therefore have been limited at the time of this research, as venues were not required to make large-scale, wholesale changes to the fabric of their venue at the time the research was undertaken.

The results show that there appears to be no significant influences of venue growth, size or disabled access on the probability of refurbishment once sector and recent refurbishment controls have been taken into account. Thus, it is not just large venues within the market place which regularly upgrade their facilities and dominate the market place. Indeed all sizes of venues aim to refurbish to remain competitive within the market place.

\section{Conclusion}

This paper has sought to identify the factors that influence the probability that a conference facility will undertake refurbishment activities. This is an important question as such information can inform conference organisers when selecting a venue and inform conference venue' mangers whether their venue is likely to be relatively outdated when compared to their competitors' venues.

Using data from 2001 relating to conference venue refurbishment across the four key conference venue categories, this paper presented the results of an econometric analysis into the factors that influence the probability of conference venues to refurbishment with a particular focus on the sector differences (purposebuilt, educational establishments, visitor attractions and hotels) and time since previous refurbishment. Controls were included for venue size and growth effects and 
whether the presence of disabled facilities influenced the probability that a conference venue would refurbish.

The results indicate that neither scale nor growth effects had an effect on the probability that a conference venue would refurbish, and that the presence of disabled facilities had no statistically significant impact on the probability that a conference venue would refurbish once sector category controls and recent refurbishment activities had been taken into account.

Our results identify clear market segmentation within conference venue refurbishment patterns, showing that it is educational establishments that were most likely to want to refurbish. This is a significant finding as past literature depicts educational establishments' accommodation as being 'utilitarian', of considerable age and with infrequent redecoration programmes. We suggest that this 'utilitarian' viewpoint is rapidly changing as educational establishments are upgrading their accommodation stock and conference facilities to offer a high quality conference product.

One drawback of this study is that the econometric analysis uses data that was collected in 2001, and did not question respondents regarding the factors that increase the likelihood of refurbishment. Future research could seek to establish whether the same results hold for the present day.

\section{Bibliography}

Alton Towers. (2008). An Award Winning Venue, http://www.altontowers.com/pages/corporate/award-winning-venues. Accessed $17^{\text {th }}$ October 2008.

Anon, (1998). The announcement to Parliament by means of a written answer to a parliamentary question. www.publications.parliament.uk/pa/cm199798/cmhansrd/vo980724/text/80724w01.htm\#80724w01 .html_sbhd1 (accessed $4^{\text {th }}$ February 2010).

Babbidge, A., (2000). UK museums: Safe and sound?, Cultural Trends, 10: 37, 1 - 35

Baker, B. (2008). The Conference Market: All the fun of the fair, http://www.bridgetbaker.co.uk/pdf/conference_venues.pdf, Accessed $8^{\text {th }}$ April 2009.

Baxter, I. (2004). From heritage to historic environment: professionalising the experience of the past for visitors. Journal of Hospitality and Tourism, 2(2), 1-14.

Bitner M and Hubbert A. (1994) “Encounter Satisfaction Versus Overall Satisfaction Versus Quality : The Customer's Voice”, in Service Quality, New Directives, edited by Rust and Oliver

Bond, N. (2007). Personnel correspondence in Whiteling I. (2007). Unusual venues found to be big draw for delegates; Meetings:review. Retrieved $24^{\text {th }}$ September 2008 from http://meetings review.com/news/view?id=856andprint $=1$.

Borer, M.C. (1972). The British Hotel Through The Age, London. The Trinity Press.

Bournemouth Borough Council. (2006a). BIC Boost to Leisure and Business http://www.bournemouth.gov.uk/News/Major_town_developments/BIC/default.asp. (accessed 27 November 2007)

Bournemouth Borough Council. (2006b). BIC Gears Up For Official Opening, http://www.bic.co.uk/News/2005/November_2005/officialopening.asp. (accessed 27 November 2007).

Bournemouth International Conference Bureau. (2007a). Bournemouth International Conference Bureau website homepage. http://www.bournemouthconferences.co.uk/index (accessed 1st February 2009).

Bowden, D., (2009). Museums - The Impact of Free Admissions. Available from www.lobbyandlaw.com.British Association of Conference Destinations. (2002). British Conference Market Trends Survey 2001. British Association of Conference Destinations, London.

British Association of Conference Destinations. (2008). BACD survey suggests market on a downer. Conference News, August. 
British Standards Institute. (2008). Guidance on accessibility of large hotel premises and hotel chains. http://www.tourismtrade.org.uk/Images/Final\%20Consumer\%20Guide_tcm12-42923.pdf. Accessed $10^{\text {th }}$ July 2009.

British Tourist Authority, (1998). British Conference Market Trend Survey 1997, British Tourist Authority, London.

Campbell, C., (2002). Disabled Access. Conferences and Incentive Travel. http://www.citmagazine.com/Features. p.16

Chetwynd, C., (2001). U.K. purpose-built centres: Room for growth: Conference and Incentive Travel. (July/August) Haymarket Publication. pp.41-51.

Clark, K. and Maeer, G. (2008). The cultural value of heritage: evidence from the Heritage Lottery Fund, Cultural Trends, 17: 1, $23-56$

Conference Oxford. (2005). Conference Oxford News Letter, November

ConferenceVenues.com. (2008). Bigger and Better BIC. http://www.conferencevenues.com/conference_venues_uk.asp?venue=Bournemouth\%20Internation al\%20Centreandconference_loc=Bournemouth (accessed 27 August 2008)

Cossons, N. (1989). Trends in Supplying the Market: Heritage Tourism-Trends and Tribulations. Tourism Management, 10(3), 192-194.

Crouch. G. I. and Louviere. J.L. (2004). The Determinants of Convention Site Selection: A Logistic Choice Model from Experimental Data, Journal of Travel Research, Vol. 43, November 2004, 118130.

Daily Echo. (2003) Karina Managing Conference Bureau. http://archive.bournemouthecho.co.uk/2003/3/18/82136.html, (accessed $1^{\text {st }}$ February 2009)

Davidson, R., and Cope B., (2003). Business Travel - Conference, Incentive Travel, Exhibitions, Corporate Hospitality and Corporate Travel, Harlow, Essex. FT Prentice Hall.

Deming, W.E., (1986). Out Of Crisis, MIT Press, Cambridge, MA.

Department for Culture, Media and Sport, (n.d). Free Admissions to Museums. http://www.culture.gov.uk/what_we_do/museums_and_galleries/3380.aspx. (accessed 4th February 2010).

Department for Culture, Media and Sport. (1998). A New Cultural Framework. www.culture.gov.uk/images/publications/dept_spending_review.pdf. (accessed 4th February 2010).

Doyle, C., (2001). Academic Venues: Conferences on Campus. Conference and Incentive Travel. September. A Haymarket publication. pp,47-50.

EdinburghFirst, (2009). The new John McIntyre Conference Centre. http://www.edinburghfirst.com/venues/johnmcIntyrecentre.asp. Accessed 28th July 2009.

Fopp, M. (1997). Managing museums and galleries. London: Routledge.

Goodall, B., (2006). Disabled Access and Heritage Attractions.Tourism, Culture and Communication, 7, 57-78.

Gosling, J. (2002). Unusual venues: An event less ordinary. Conference and Incentive Travel. November/December, 23-28.

Hassanien, A., and Losekoot E. (2002) The application of facilities management expertise to the hotel renovation process, Facilities, Vol. 20(7/8), 230-238.

Hayes, D., and Slater, A. (2002). Rethinking the missionary position-the quest for sustainable audience development strategies. Managing Leisure, 7(1), 1-17.

Headley, D.E., and Choi, B., (1992). Achieving Service Quality Through Gap Analysis and Basic Statistical Approach, The Journal of Services Marketing, 6(1), pp.5-12

Heritage Lottery Fund. (2002). Heritage Grants: Grants of £50,000 or more. London: Heritage Lottery Fund

Heritage Lottery Fund. (2009). About Us. http://www.hlf.org.uk/aboutus/Pages/AboutUs.aspx (accessed 4th February 2010)International Association of Congress Centres. (2008). AIPC Apex Award 2008, http://www.aipc.org/award_2006.html. (accessed 27 August 2008).

Joint Consultative Committee. (2007). Notes of the meeting of the Joint Consultative Committee (GROUP 5) BIC / Pavilion held on the $25^{\text {th }}$ October.

http://www.bournemouth.gov.uk/Library/Committee_Meetings/PERSJCC/Reports/31_January_200 8/Report\%20H\%20JCC\%20Minutes\%2025\%2010\%2007\%20BIC\%20Pavilion.pdf. (accessed $1^{\text {st }}$ February 2009).

Johnson. D. (2007). Personnel correspondences cited in Macdonald (2007) Refurbished Hotel New Blossoms In The Heart Of Chester, http://www.macdonaldhotels.co.uk/press/press_170407_Blossoms_Refurbished.htm. (accessed 0105-07). 
King, C.A., (1987). A Framework for a Service Quality Assurance System, Quality Progress, September, pp.27-32.

Ladkin, A. and Spiller, J.E., (2001). The international MICE Industry: Challenges for Research. CAUTHE National Research Conference, Capitalising on Research $7^{\text {th }}-10^{\text {th }}$ February. Canberra, Australia

Lawson, F. (2000). Congress, Conventions and Exhibition Facilities. Oxford. UK. Architectural Press

Leask, A. and Digance, J., (2001). Exploiting Unused Capacity: Sports Stadia and the Meetings Industry. Proceedings of the Conference / Expo Summit IX. February. Roehl, W (editor). University of Nevada Vas Vegas, pp.57-71.

Leask, A., Fyall, A. and Goulding, P., (2000). Revenue Management in Scottish Visitor Attractions In Ingold, A. and McMahon-Beattie, U. (editors) 2000). Yield Management: Strategies for the Service Industries. 2nd ed. London: Cassell.

Leask, A. and Hood, G., (2000). Unusual Venues as Conference Facilities. Proceedings of The Conference / Expo Summit VIII, February,. Roehl, W.(editor) University of Nevada Vas Vegas.

Leask, A. and Spiller, J.E. (2002). U.K. Conference Venues: Past, Present and Future. Journal of Convention and Exhibition Management. 4 (1). (2002). New York. London. Oxford. The Haworth Press. pp.29-54.

Macdonald. (2007). Refurbished Hotel New Blossoms In The Heart Of Chester, http://www.macdonaldhotels.co.uk/press/press_170407_Blossoms_Refurbished.htm. (accessed 0105-07).

McCabe, V. S., (2002). Convention Hotels in Australia: Trends and Issues. In Weber, K and Chon, K. (editors), 2002 . Convention Tourism: International Research and Industry Perspectives. New York. London. Oxford. The Haworth Hospitality Press.

McPherson, G., (2006). Public memories and private tastes: The Shifting Definitions of Museums and their Visitors in the UK. Museum Management and Curatorship. 21. p. 44-57

Meetings Industry Association, (2000). U.K. 2000 Conference Market Survey, Broadway, Meetings Industry Association. Worcs: Author.

Meeting Industry Association, (2001). Survey of Conference Clients, Spring, Meeting Industry Association $\left(13^{\text {th }} \mathrm{Ed}\right)$, Worcs: Author.

Morris, J., (2005). Missing evidence: Why Museums Should Learn from the Past, Cultural Trends, 14: $1,107-111$.

Nicholson D. (2000). London: City of the Future. Conference and Incentive Travel. A Haymarket Publication. March, 36-38.

Paine A., (1993). The University Conference Market, Insight, May.

Peak District, (2009). Conference with US (part of the University of Sheffield). http://www.peakdistrict-nationalpark.com/the-university-of-sheffield-group-accommodation.aspx. Accessed 28th July 2009.

Pemble, A. (2000). Unusual Venues: Pursuing Perfection. Conference and Incentive Travel. November/December, 33-35.

Pemble, A., (2002). Academic Venues: Educated Choice. Conference and Incentive Travel. A Haymarket Publication. (September), pp51-54.

Richards, G., Richards, B., (1994). Developing Corporate Business for Hotel Through Conferences and Exhibitions. Journal of Vacation Marketing 1(1) pp.61-69.

Robinson, L. S. and Callan, R.J., (2001). The U.K. Conference and Meetings Industry: Development of an Inventory for Attributional Analysis, Journal of Convention and Exhibition Management. Vol. 2 (4), pp.65-79

Robinson, L. S. and Callan, R.J., (2003). U.K. Conference Delegates’ Cognizance Of The Importance Of Venue Selection Attributes, Advances in Convention, Journal of Convention and Event Tourism. pp. 77-95.

Rogers, T., (1998). Conferences: A Twenty-first Century Industry. Harlow, Addison Wesley Longman.

Rottenberg, B. (2002). Museums, Information and the public sphere. Museum International. 54(4)., 2128

Saunders, D. (2001). Unusual Venues, Remarkable Locations. Conference and Incentive Travel. November/December, 37-42.

Seekings, D., (1996). How to Organise Effective Conferences and Meetings. GB. Kogan Page p.50

Selwood, S., and Davies, M., (2005). Capital Costs: Lottery Funding in Britain and the Consequences for Museums. Curator: The Museum Journal. 48(4). 439 - 465

Shallcross, W., (1998). The British Conference Market, Insights, January.

Shelton, E. J., and Tucker, H. (2005). Tourism and disability: Issues beyond access. Tourism Review International, 8. 211-220. 
Shetty, Y.K., Ross, J.E., (1985) Quality And Its Management In Service Business, Industrial Management, November/December, pp.7-12.

Spain, J. (2007). Unusual Venues; What challenges do they pose for suppliers, Meetings:review. Retrieved $22^{\text {nd }}$ September 2008 from http://meetingsreview.com/news/view?id=768andprint=1.

Stancliffe, J., (n.d.) Collecting Cultures Grants for Developing Museum and Gallery Collections, http://www.mlalondon.org.uk/uploads/documents/Collecting_Cultures_HLF.pdf. (accessed 5th February 2010).

Stipanuk, D.M. and Roffmann, H. (1996), Hospitality Facilities Management and Design, 2nd ed., American Hotel and Motel Association, Lansing, MI.

Swarbrooke, J., (1996). The Development and Management Of Visitor Attractions, Oxford, Butterworth Heinemann.

Taylor, D., and Bush, D. (1974). The Golden Age of British Hotels, London: Northwood

Tally D., (1991). Total Quality Management, Performance And Cost Measures: The Strategy for Economic Survival, ASQC Quality Press, Milwaukee, WI.

Troye, S., Ogaard, T. and Henjesand I., (1995). The Triple Importance Of Service: An Empirical Model Of Service And Product Quality, in Bergadaa, M., (ed), Marketing Today And For The $21^{\text {st }}$ Century, Ecole Superieure des Science Economiques et Commerciales, Cergy-Pontoise, pp11351154.

Twickenham Experience. (2008). New South Stand, http://www.twickenhamexperience.com/aboutus/new-south-stand (accessed 15 February 2009).

University of Edinburgh. (2009). The Duke opens the John McIntyre Conference Centre. http://www.ed.ac.uk/schools-departments/accommodation-services/about/official-opening (accessed 02 Feb 2010)

Walters, D., (2009). Approaches in museums towards disability in the United Kingdom and the United States, Museum Management and Curatorship, 24: 1, $29-46$

Whitfield, J. E. (2005). An Analysis and Critique of an Evolving Conference Industry within the UK from Post War to the Present Day, PhD dissertation, Bournemouth University, Bournemouth, Dorset, UK.

Whitfield, J.E. (2007). Why build purpose-built conference venues? Forecasting new build Journal of Retail and Leisure Property, 6:1, 47-60Whitfield, J. E. (2009). Why and How UK Visitor Attractions Diversify Their Product to Offer Conference and Event Facilities. Journal of Convention and Event Tourism,10:1,72 - 88

Whitfield, J.E. (2010). The Cyclical Representation of the UK Conference Sector's Lifecycle - The Use of Refurbishments as Rejuvenation Triggers. Tourism Analysis Vol. 14. (4)(pending)

Wills, A. (2002). Museums and Attractions: Stimulating Settings. Conference and Incentive Travel. April, 37-40.

Zeithaml, V.A. and Bitner M.J. (1996). Services Marketing, The McGraw-Hill Companies Inc, New York 
Table 1: Econometric results

\begin{tabular}{|c|c|c|c|c|c|}
\hline & $\overline{11}$ & 2 & $\overline{3}$ & 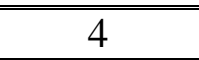 & $\overline{5}$ \\
\hline$N$ & 434 & 434 & 434 & 205 & 205 \\
\hline Constant & $\begin{array}{c}0.382^{* * *} \\
(0.166)\end{array}$ & $\begin{array}{c}0.317 * * * \\
(0.186)\end{array}$ & $\begin{array}{c}0.288^{* * *} \\
(0.226)\end{array}$ & $\begin{array}{c}0.290 * * * \\
(0.226)\end{array}$ & $\begin{array}{c}0.297 * * * \\
(0.227)\end{array}$ \\
\hline Refurbishment in last 3 years & $\begin{array}{c}2.364^{* * *} \\
(0.209)\end{array}$ & $\begin{array}{c}2.410^{* * *} \\
(0.212)\end{array}$ & $\begin{array}{c}2.487 * * * \\
(0.214)\end{array}$ & $\begin{array}{c}2.505^{* * *} \\
(0.215)\end{array}$ & $\begin{array}{c}2.263 * * * \\
(0.227)\end{array}$ \\
\hline Education facility & & $\begin{array}{l}2.164^{*} \\
(0.438)\end{array}$ & $\begin{array}{l}2.147^{*} \\
(0.439)\end{array}$ & $\begin{array}{l}2.318^{*} \\
(0.447)\end{array}$ & $\begin{array}{l}2.177^{*} \\
(0.453)\end{array}$ \\
\hline Visitor attraction & & $\begin{array}{l}1.795^{* *} \\
(0.271)\end{array}$ & $\begin{array}{l}1.890^{* *} \\
(0.275)\end{array}$ & $\begin{array}{l}1.912 * * \\
(0.276)\end{array}$ & $\begin{array}{l}1.769^{* *} \\
(0.282)\end{array}$ \\
\hline Purpose built facility & & $\begin{array}{c}1.250 \\
(0.311)\end{array}$ & $\begin{array}{c}1.232 \\
(0.311)\end{array}$ & $\begin{array}{c}1.295 \\
(0.315)\end{array}$ & $\begin{array}{c}1.173 \\
(0.325)\end{array}$ \\
\hline Hotel & \multicolumn{5}{|c|}{ Control variable } \\
\hline $\begin{array}{l}\text { Change in the number of } \\
\text { events in the last } 3 \text { years }\end{array}$ & & & $\begin{array}{c}1.081 \\
(0.112)\end{array}$ & $\begin{array}{c}1.080 \\
(0.112)\end{array}$ & $\begin{array}{c}1.083 \\
(0.114)\end{array}$ \\
\hline Floor space & & & & $\begin{array}{l}1.000 \\
(0.001)\end{array}$ & $\begin{array}{c}1.000 \\
(0.001)\end{array}$ \\
\hline Disabled access present & & & & & $\begin{array}{c}1.527 \\
(0.307)\end{array}$ \\
\hline $\begin{array}{l}\text { Omnibus test for model } \\
\text { coefficients }\end{array}$ & $17.714 * * *$ & $24.608 * * *$ & $27.999 * * *$ & $29.050 * * *$ & $30.962 * * *$ \\
\hline Hosmer and Lemeshow test & $0.050 * * *$ & 0.743 & 3.738 & 7.685 & 6.101 \\
\hline -2 Log likelihood & 563.416 & 556.522 & 553.131 & 552.080 & 550.168 \\
\hline
\end{tabular}

Notes: In all estimates, the dependent variable is whether the facility will refurbish the centre in the near future. All regressions are estimated using logistic regression and the values presented are oddsratios. Standard errors are in parentheses. $* * *, * *$ and * signify significance at the $1 \%, 5 \%$ and $10 \%$ level respectively. 